\title{
オナガガモ雌の雄変例
}

\author{
黑 田 長 禮*
}

鴨にはニワトリなどと同じ様に主に飼藓中のもので古が永年飼秃ている内に部分的に羽色 が雄変して来る場合がある。ニワトリでは早が鷄冠が伸びたり，今の如き時を作る鳴声を発す るものがある。勿論産卵はしない。解剖すると卵巣は不判明か縮少して即ち早でなくなってい ることが多い。これは生殖器の何等かによる変異であろう。そして距は出てこない。

鴨の場合り恐らく斯様であろうと思うが，外部の変化に気付くのみで未だその個休を解剖し たことがない。是迄の例としては私 $(1929 ， 1939)$ はオナガガモに1例，乙れは羽田鴨場で採 集し飼養の平の今変（「鳥」6 (27)参照）と永く飼養したオシドリ 古が何年目かに突然羽衣脱新 のときに数羽の占羽，殊に銀杏羽も顔を出すに至ったことを知る。この場合写真は撮ってある が，この鳥は間しなく野犬の襲来で整死したので仮剝製で残っている。時は 1966 年 2 月 7 日 で，10年間飼養の鳥であった（飼養許可による鳥）。

今回笹川昭雄氏が 1974 年 2 月上旬上野不忍池で撮影された才ナガガモの雌玟雄型の写真は上 記の例に入ると私は思う。よほどの老成雌が令変したものと思う。これは前例より脇の斑が明 瞭で且つ尾が長い。

一見似て見えるオナガガモ Kerguelen Pintail (Anas acuta eatoni (Sharpe)) ではない ことは斑紋や前頸が白色無斑であって一致していないことの外，この Kerguelen の亜種は南 インド洋の Kerguelen 島の留鳥であって人力により北へ持ち来たされた英仏の例の外は自ら 北進の渡りはなし得ないと信ずる。但し近年知張り南インド洋の St. Paul 及び Amsterdam Islandsに移入されている。

要するに雉科や鴨科のような所謂絧鳥の早が極く稀れではあるが含変する例は時々知られて いるのである。
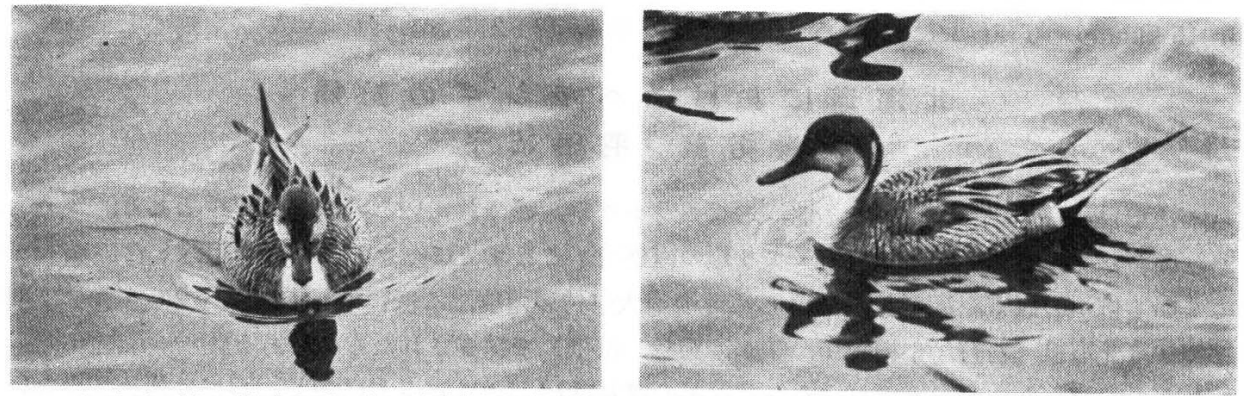

オガガモ雌の雄変個体（上野動物園不忍池にて。1974年 2 月，笹川佋雄氏撮影）

A masculinized female pintail Anas acuta acuta (Shinobazu Pond, Ueno, Tokyo. Feb.

1974) (Photo Akio Sasagawa)

附記一以上を書いた後，神奈川県立博物館の中村一恵氏（1976年 2 月 23 日受信）から同じ 不忍池で1976年 2 月10日にオナガガモ 1 羽の異常羽を撮影し私に寄贈され多分早の合変であろ うとの手紙を受けた。これは前の䈎川氏の1974年の写真に比し大に異っていて白味勝ちで一見 同一鳥とは思われない。しかしオナガガモ早の含変たることは確からしく思える。

* (107) 東京都港区赤坂 2 丁目 17 番地 10 号 
参考文献 : Delacour, Jean 1956. The Waterfowl of the World. Vol. 2: 129 135, pl. XIV. London.

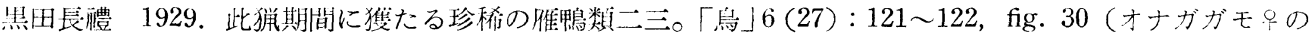
含変, 羽田採集, 1928).

黑田長禮 1939. 倠と鴨 pl. 67 の説明。

Scott, Peter 1957. A Coloured Key to the Waterfozel of the World. P. 50, Col. figs. London.

\section{Examples of masculinized female \\ pintails Anas acuta}

\section{Nagamichi Kuroda}

A presumed old female pintail Anas acuta with masculinized plumage pattern is here reported with its photo taken by Mr. Akio Sasagawa at Shinobazu pond, Ueno Zoo, Tokyo, early February, 1974. It has rough flank markings and elongated central tail feathess.

Another example of different plumage pattern also found at the same pond, photographed a 10 February 1976, by Mr. Kazue Nakamura is added.

Kuroda (1929, '39) had reported another old record of the pintail and a female Mandarin duck Aix galericulata was masculinized when molted after long kept in author's aviary.

(107) Akasaka, 2-17-10, Minato-ku, Tokyo 